\title{
Patterns of Social Embeddedness in Later Adulthood: Gender and Other Covariates²
}

\section{Sarmitė Mikulionienè, Inga Gaižauskaitė, Vaidas Morkevičius}

\begin{abstract}
The concept of social exclusion is widely used in academia and social policy discourse in European countries. However, one of the constituents of social exclusion, namely, exclusion from social relationships, remains unclear and underdeveloped both conceptually and empirically. Moreover, knowledge on the patterns of exclusion from social relationships among men and women in later adulthood is even less advanced. Therefore, we developed a multidimensional scale for measuring an individual's level of embeddedness in social relationships and examined the gender patterns of social embeddedness. We applied latent class analysis to survey data collected on a sample of 2015 residents of Lithuania, Latvia, and Estonia aged 50+. We derived a seven-class model based on a continuum from strong to weak social embeddedness. We identified two classes with a high level of exclusion from social relations and, conversely, two classes with a high level of social embeddedness. Subsequent multinomial regression analysis revealed that gender was a statistically significant predictor in the cases of the most excluded class and one of the most socially embedded classes.
\end{abstract}

Keywords: social relationships, social exclusion, latent class analysis

Mikulionienè, Sarmitè, Gaižauskaitè, Inga, Morkevičius, Vaidas. 2021. Patterns of Social Embeddedness in Later Adulthood: Gender and Other Covariates. Gender a výzkum / Gender and Research 22 (1): 36-58, http://dx.doi.org/10.13060/gav.2021.013.

Like many leading researchers in the field (Walsh et al. 2017; Regenmortel et al. 2016; Levitas et al. 2007; Burchardt et al. 2009), we understand exclusion from social

\footnotetext{
2 This article was supported with funding from the European Social Fund (project no. 09.3.3-LMT-K-712-01-0063) under a grant agreement with the Research Council of Lithuania (LMTLT). We thank Dr Jolanta Aidukaitė and Dr Inga Blažienè for useful discussions and for comments on the manuscript and Dr Ramune Dirvanskiene for contributing to the construction of the survey instrument.
} 
relations as one of the important elements of overall social exclusion in later life. Following Walsh et al. (2017: 92), we see social exclusion as

a complex process that involves the lack or denial of resources, rights, goods and services as people age, and the inability to participate in the normal relationships and activities, available to the majority of people across the varied and multiple domains of society. It affects both the quality of life of older individuals and the equity and cohesion of an ageing society as a whole.

Domains that contribute to old-age social exclusion include exclusion from material and financial resources, social relations, services, amenities and mobility, civic participation, neighbourhood and community, and the sociocultural aspects of society (Walsh et al. 2017).

It cannot be said that exclusion from the domain of social relations is less explored than other domains; however, some studies (Baumgartner, Burns 2014; UNECE 2016) show that there are still too many uncertainties, ambiguities, and challenges in operationalising and measuring the phenomenon of exclusion from social relations. The quality of measuring instruments of social inclusion was assessed as indeterminate (Cordier et al. 2017: 23). As many as 45\% of the scales that are described in the literature (Cordier et al. 2017) lack a methodological (psychometric) quality assessment, which in turn limits their diagnostic power and, consequently, the possibility of combating exclusion from social relations. It is already known from other studies that social exclusion (or specifically exclusion from social relations) has multiple negative consequences for a person and decreases their wellbeing. However, we still lack a better understanding of the patterns of social exclusion among older people (and specifically their inclusion in social relationships) in Eastern European countries (Mikulionienè et al. 2018). Even less is known about differences relating to the inclusion of older women and men in social relationships. Therefore, we applied a new scale for measuring a person's level of embeddedness in social relationships and examined gender differences according to this scale.

The aim of the article is to examine profiles of social embeddedness among older (50+) men and women in the Baltic States and to predict the probability of older people belonging in empirically identified groups according to their levels of embeddedness in social relations. Therefore, we seek to answer two research questions: (1) What are the patterns of social embeddedness (conceptualised via dimensions of social participation, civic participation, and sense of belonging) among older (50+) men and women? (2) What are the predictors that affect the probability of belonging to groups of people identified according to their different levels of embeddedness in social relations in later life? To answer these questions, we analyse sociological 
survey data collected in the research project 'Building the Welfare of Older People: Empowerment Policies, Monitoring Indicators, and Older Voice'. We employ latent class analysis (LCA) with covariates in order to identify patterns of engagement in social relationships and study their predictors.

\section{Conceptualising and measuring social embeddedness in later life}

International scholarship (Antonucci 1990; Pinquart, Sörensen 2000; Berkman et al. 2000; Gyasi et al. 2019; Ye, Zhang 2019) strongly recognises the importance of social embeddedness for older people's wellbeing. Moreover, a lack of meaningful social environments and weak social embeddedness are considered important risk factors for social exclusion in old age (Walsh et al. 2017; Regenmortel et al. 2016; Yanicki et al. 2015; Barnes et al. 2006). However, researchers and policymakers are still not satisfied with the available statistics on social exclusion in general and on exclusion from social relationships in particular (UNECE 2017: 28-32; Ward et al. 2014; Labonté et al. 2012).

As we are interested in measuring the full spectrum of older people's social relationships (recognising that, between the two extremes of either inclusion in or exclusion from social relationships, there are many intermediate positions that are possible), we decided to explore social embeddedness, which, as we understand it here, refers to the social relations that foster a sense of belonging (see Palmberger 2017). Social embeddedness is continuously created and maintained through everyday interactions with others (Wenger et al. 2007). It includes daily routines with others at home and outside the home (for instance, at the workplace or a place of learning), during leisure and hobby activities, and in different local (and spiritual) communities and in society as a whole, and it relates to the sense of belonging a person has to these different-level groups. We base our definition on the synergy of theoretical insights coming from sociology and social psychology. American sociologist Robert Ezra Park (1926: 11) argued that 'society exists in and through communication', and individuals who share a common experience and maintain a common life create interaction networks. These social networks are essential for the creation and maintenance of social relationships among individuals. Social relationships can be investigated and measured (Park 1924). Social psychologist Kurt Lewin (1951), who examined the experiences and perceptions of belonging to a group, showed that members of groups develop shared perceptions of the world around them. A sense of belonging to the community is a vital component of identity, and Maslow (1954) argued that belonging is a basic human need. According to Hagerty et al. (1992), a sense of belonging is the experience of being both personally involved and integrated within an environment or system. Therefore, to fully grasp social embeddedness we base 
our study not only on behaviour and social networks (social and civic participation) but also on a subjective characteristic - people's sense of belonging.

According to Cordier et al. (2017), contemporary researchers' experience of measuring social inclusion ${ }^{1}$ can be summarised as focusing on three basic components of inclusion: (1) participation (i.e. economic, social, and spiritual), (2) connectedness and a sense of belonging (i.e. having a sense of connectedness to one's family, friends, neighbours, the wider community), and (3) citizenship (i.e. political and general community engagement, demonstrating altruism, and having access to community services). Cordier et al. (2017) found 25 instruments for measuring social inclusion that have been documented in the literature. They note that, so far, the different instruments that have been used have combined, in different proportions, indicators from one or two of the three components mentioned above, but none of the instruments has covered all three.

Drawing on other studies in the field (Cordier et al. 2017; Palmberger 2017; Baumgartner, Burns 2014; Levasseur et al. 2010), we constructed an analytical model to cover the three domains that make up the core of what constitutes the social embeddedness of older persons: social participation, civic participation, and a sense of belonging. Our model includes an individual's social participation because it captures the diversity and frequencies of everyday social interactions (objective); civic participation because it shows higher-order social activities (levels 5 and 6 of social activities in the typology of Levasseur et al. (2010)); finally, a sense of belonging because it reflects what these relationships mean to the ego (subjective). This set of dimensions ensures that our model is consistent with the argument of many contemporary scientists: it is vital to study objective and subjective indicators of social relationships (Burholt et al. 2020; Baumgartner, Burns 2014).

Social participation. Researchers have shown that social participation is an essential predictor of the social inclusion and wellbeing of an individual (Levasseur et al. 2008, 2010). However, how the concept of social participation is defined in the literature still varies (Dijkers 2010; Piškur et al. 2013). Some researchers (Piškur et al. 2013: 3) point out that social participation can be related to consumer activity, communication, or a greater level of involvement in society. Others distinguish three hierarchical types of social participation (starting from the bottom up): collective, productive, and political participation (Bukov et al. 2002). Levasseur et al. (2010: 2,

\footnotetext{
${ }^{1}$ Cordier et al. (2017) used the term social inclusion in two ways. In the first part of the article, its definition was based on the classical perception of the term. In the empirical part, according to the keywords for the record-search employed (social participation, social capital, social responsibility, community inclusion, social justice, social acceptance, social reinforcement, community participation) and the scales found, it can be ascertained that a narrower concept was used. It mainly covered social relationships and left out other domains of social inclusion/exclusion.
} 


\section{STATI / ARTICLES}

16) looked at social activities, and after a systematic review based on (1) the level of an individual's involvement with others and (2) the goals of these activities, they distinguished six levels of social activities:

1) doing an activity in preparation for connecting with others, 2) being with others, 3) interacting with others without doing a specific activity with them, 4) doing an activity with others, 5) helping others, and 6) contributing to society.

Investigators (Levasseur et al. 2010: 2) defined levels 3 through 6 as social participation, and levels 5 and 6 as a higher-order social participation that they call social engagement. In our model, it is just as important for us to include level 3-6 social activities and clearly delineate levels 5 and 6 . It is also important to capture several parameters when measuring social participation: the list of social networks (sufficient number and diversity) in which the person is involved (this is a prerequisite for long-term, meaningful relationships); the frequency of his/her social interactions, and the contexts in which the interactions take place (in a household or outside).

Therefore, we include in our measurement instrument variables that indicate the level of social participation: social participation in micro-groups (hosting guests and visiting others in their home; interaction with children, grandchildren, parents, and other relatives; interaction with friends, co-workers, and neighbours), social eating (in cafes and restaurants) as one of the social consumption activities, the consumption of culture (visiting cinema, theatres, museums, etc.), and participating in arts and sports activities. We also include 'spiritual' activity, which refers to social participation in religious events. In Cordier et al.'s (2017) classification, this category is also mentioned separately from social participation; in our opinion, it is not necessary to distinguish the declared spiritual activity from its hidden social function - being a member of a religious community also brings a person an important sense of belonging to the community (Durkheim [1912] 1995).

Civic participation. This encompasses social relationships that transcend the boundaries of individual and interpersonal and rise to the societal level, where a person is socially engaged in pursuing the benefit of a community or society. Many authors define this as a different type of social activity (Walsh et al. 2017; Ward et al. 2014; Scharf et al. 2005). However, following Levasseur et al. (2010), we argue that although this activity differs from everyday socialisation activities, in its essence it is also a social participation activity, just a different type of such activity - performed in relation to the wider, societal level, while bearing in mind the direct or indirect impact on others' wellbeing.

Thus, we include in our measurement instrument variables that indicate the level of civic activity: certain more reactive types of civic participation - following national 
news in the mass media; voting in elections; and certain proactive types of civic participation - participation in the community (the person worked for the community, expressed opinions on issues important to the community/society, participated in protests, signed a petition, etc.) and engagement in altruistic activities (provided help (for non-relatives) without remuneration; volunteering).

A sense of belonging. A sense of belonging is based on relationships with social groups and feelings of emotional attachment to the related group (Taket et al. 2009; Lee, Robbins 1995). It is quite an informative indicator: studies have reported that perceived social connectedness has a significant positive association with health status (Ashida, Heaney 2008), and perceived social connectedness is positively associated with social network density and proximity (Ashida, Heaney 2008). The literature reveals that several measures of belongingness have been developed: the Sense of Belonging Instrument (SOBI) (Hagerty, Patusky 1995); the Social Connectedness Scale (Lee, Robbins 1995); and the Social Connectedness Scale-Revised (SCS-R) (Lee et al. 2001). However, they were designed for the general population or college students. Belongingness reflects a person's emotional attachment in the context of his or her social connections. Therefore, we feel that it is vital to capture a sense of belonging as a separate domain of social embeddedness because high levels of social and civic participation do not always result in a correspondingly high sense of belonging (Crisp 2010).

To capture this dimension in our instrument, we include a subjective assessment of the quality of family relationships (the level of tension in the relationships between household members, the presence of a person in the household with whom a person can speak sincerely, and a feeling of being close to and needed by one's family). Since social relationships include a person's involvement in social networks at various levels, we also believe that it is essential to include here the indicator of a respondent feeling close to and needed by people in his/her neighbourhood and the feeling that he/she is a full-fledged member of society.

The gender dimension. Traditional gender roles that permeate our lives may have a strong impact on older people's social embeddedness. However, little is known about how men and women organise their social relationships in later life, especially in the region of Eastern Europe. We know only some relatively well-calculated statistical parameters that apply to the Baltics as well: older women live longer than men, the widowhood rate among them is higher than among men, their physical health and economic wellbeing are lower than that of men of the same age (Pinquart, Sörensen 2001). A truth that seems also to apply well to the Baltics is that older women experience continuing disadvantages in income, status, and power (Inglehart 2002). However, when it comes to characteristics that are more difficult to define without ambiguity and to express in numbers, the research results on gender differences do 


\section{STATI / ARTICLES}

not provide convincing evidence. For instance, multiple attempts to examine gender differences in life satisfaction have produced contradictory results: some authors agree with the gender similarity hypothesis, others find mixed trends or apparent gender differences (see Joshanloo, Jovanović 2019). Gender differences in life satisfaction are small (Pinquart, Sörensen 2001), levels of loneliness, even across the whole life span, demonstrate no apparent gender-specific patterns (Maes et al. 2019). According to Becker et al. (2019), it seems that symptoms of depression are more common among older men than among women of the same age.

\section{Research methods}

We collected our data by means of survey research. Representative surveys of the residents of Lithuania, Latvia, and Estonia ${ }^{2}$ aged 50 years and older were conducted in the three countries between October and December 2019. The total size of the sample was 2,015 respondents (800 in Lithuania, 605 in Latvia, and 610 in Estonia). The survey was administered in the form of face-to-face interviews in the home of each respondent (PAPI ${ }^{3}$ in Lithuania and $\mathrm{CAPI}^{\prime} \mathrm{s}^{4}$ in Latvia and Estonia). Nationally representative samples of populations aged $50+$ in each country were drawn from the national statistics offices' latest population data ${ }^{5}$. The sampling procedure in each country covered all the territory of the country. The samples were designed using a method to ensure proportional representation, where households were selected randomly (random route method) and the individuals within the household selected using the last-birthday rule combined with the quota method. The gender distribution in the overall sample is $61.2 \%$ and $38.8 \%$ male respondents (respectively, $60.2 \%$ female and $39.8 \%$ male respondents in Lithuania; $64.8 \%$ female and $35.2 \%$ male respondents in Latvia, and $59.0 \%$ female and $41.0 \%$ male respondents in Estonia).

The structured survey questionnaire included measures of health status, the level of independence in day-to-day activities, safety and trust, economic participation, participation in education, social participation, connectedness and a sense of belonging, citizenship and rights, services, help, internet use, subjective wellbeing, and sociodemographic characteristics. The core questionnaire was constructed in the Lithuanian language and then translated into Latvian, Estonian, and Russian for use in the fieldwork.

\footnotetext{
${ }^{2}$ Lithuania, Latvia and Estonia are small (in terms of population), unique and independent countries. However, because of their similar political and socio-economic experiences and transitions in the 20th century, these countries are often presented under their regional name - the Baltics.

3 Paper-based personal interview.

${ }^{4}$ Computer-assisted personal interview.

${ }^{5}$ Respectively, Statistics Lithuania, the Central Statistical Bureau of Latvia, and Statistics Estonia.
} 
For the purposes of the study, we used latent class analysis (LCA) with covariates (Collins, Lanza 2010) implemented in the $R$ statistical software package LCCA (Schafer, Kang 2013). We decided to employ LCA because it is a case-oriented method and thus differs from other, similar methods that are more variable-oriented. It was important to identify potentially diverse categories (classes) of older people with regard to the level of their social embeddedness in (or, conversely, - their exclusion from) social relations. For the task of identifying the latent classes, we used three dimensions of social embeddedness (composed of a series of indicators, see Table 1): social participation, civic participation, and a sense of belonging. This allowed us to identify classes along the continuum of social embeddedness-exclusion from social relationships.

After a thorough revision of the 2- to 10-class models initially retrieved (see the Annex, Table 1), we chose a 7-class model as the most relevant (and statistically sound) one for the purpose of our study. Although the 5- and 6-class models also would have allowed us to identify meaningful class patterns, the 7-class model was more sensitive to the important details across the classes.

For further analysis of the predictors of belonging to one of the seven classes, we employed LCA with covariates (resembling a multinomial regression analysis in the presentation of results). We compared the predicted probabilities of belonging one class or another using the following covariates: gender, subjective economic status of a household, subjective health status, achieved education, participation in education, household size (number of people living together in a household), marital status, knowledge of the titular language (the official language of a country of residence), employment status, in-group trust (a composite measure of trust in family, people in the neighbourhood, and people one knows personally), out-group trust (a composite measure of trust in people one meets for the first time and trust in people of another religion and another nationality), ${ }^{6}$ and subjective wellbeing (a composite scale) (Kairys et al. 2013).

\section{Results}

Based on the results of the LCA, in the 7-class model we were able to clearly identify two classes with a high level of social embeddedness (class 6 and class 1) and two classes that are highly excluded from social relations (class 3 and class 7) (see Table 1 for more detail). The remaining classes $(2,4$, and 5$)$ are partially socially embedded,

\footnotetext{
${ }^{6}$ We included a standard measure applied in the European Values Study, Wave 2017 (European Values Study, 2018); it was also used in the World Values Survey, Wave 2005-2006, and some other international comparative surveys.
} 
and as we reveal in the class profile descriptions below, the people in these classes have distinct patterns of characteristics across the dimensions of social embeddedness.

\section{Social embeddedness class profiles}

We present the class profiles in a decreasing order in terms of their overall level of social embeddedness, from the most embedded class 6 to class 3, which is mostly excluded from social relations.

Class 6 - the highest level of social embeddedness. This class includes older people who are overall the most active. They are socially engaged at the highest level (above the average compared to members of other classes) in every dimension of social embeddedness: social participation; civic participation, and a sense of belonging. They have higher scores for each indicator of every dimension of social embeddedness than the members of other classes do. They stand out for their high rates of regular socialising (hosting guests and visiting others), they interact more regularly with their children and grandchildren (as well as with other categories of people); they tend to volunteer, provide help, and be more civically engaged than others. Their sense of belonging (to family, community, and society at large) is also higher.

Class 1 - a high level of social embeddedness. The members of this class are older people who in most cases live in one-person household but otherwise are well socially embedded. The level of their social embeddedness is close to class 6 . Their scores of social embeddedness are above the average compared to the remaining classes in terms of their social participation, networks, and civic participation. The overall level of civic participation of class 1 is only slightly lower than that of class 6 . However, members of class 1 objectively lack an important social resource - a network of family members who share the same household. Thus, class 1 is characterised by a modest sense of belonging: overall it is lower compared not only to class 6 but also to class 2, class 4, and class 5 . The latter classes have a lower overall level of social embeddedness than class 1, although the sense of belonging is lower in class 1. Therefore, living in a one-person household may affect a person's sense of belonging to others in various ways. Nevertheless, members of class 1 apparently compensate for the lack of family networks through active engagement in the community and through civic participation.

Class 2 - partial social embeddedness. Although members of class 2 live in a household with other family member(s), they seem to be slightly detached from familial social relations. They are also more involved in activities in the public space. The overall level of social embeddedness is a little lower but still close to that of class 1; however, class 2 differs in terms of of its household composition (people in this class are thus more likely both to receive emotional support and to experience tensions among household members than those in class 1). Nevertheless, the social 
participation of class 2 is selective: these people are less engaged with neighbours and the family network outside their household (presumably they still share a household with their children and do not yet have grandchildren) but more often than sample average they socialise in the public space, and attend activities in sports and the arts. They are active in civic participation (and, like class 6 and class 1, at an above-average level). However, the level of their sense of belonging is below the sample average. The members of this class have a weaker sense of belonging to family, community, and society at large. Also, their probability of experiencing tensions with household members is at the same level as that observed for class 2.

Class 4 - partial social embeddedness. The members of class 4 are well integrated into familial networks both in and outside the household (children and grandchildren). Their social participation is selective (though in a different way than for class 2). They are deeply engaged in networks of family members, relatives, and neighbours, and they more often that other classes interact with grandchildren (at a level comparable to class 6). However, socialising outside the family network is rarer for this class than the sample average (except in relation to religious practices). Passive forms of civic engagement prevail in class 4 (following national news and voting). This class is less likely to engage in civic activity or volunteer. Class 4 has overall a strong sense of belonging (close to the level observed for class 6 and above the sample average). Among the indicators of a sense of belonging, feeling close to one's family is especially strong among members of class 4 . It is important to note that the probability of belonging to this class is the highest among older people in the Baltics.

Class 5 - partial social embeddedness. People in this class stand out for what seems to be their disrupted ties to social networks (both extended familial and community) outside their household. In some respects, they are like class 2: they live in households with other family member(s) and their social participation in public spaces (e.g. social eating, consumption of culture, religious practices) is above the sample average. However, their civic participation is centred on volunteering and helping others. Despite their low level of interaction within social networks outside the household, the overall level of their sense of belonging is rather strong (it is stronger than that of the more socially embedded classes 1 and 2). Presumably, the lack of a wide social network is compensated for by the solid relationships they have with family members within the household and the meaningfulness of volunteering and providing help. It is important to note that older people in the Baltics are the least likely to belong to this class. However, as the discussion of the predictors used in the regression analysis will show, members of this class may constitute a specific group of citizens.

Class 7 - a low level of social embeddedness. Most members of class 7 live in one-person households, but in contrast to class 1 they score low (below the average) on most of the indicators of social embeddedness. Their social network is limited 
to micro groups outside the household (primarily, neighbours, also relatives). Their social participation is weak in all other respects. Though at a lower rate than the average, they tend to host guests or visit others and attend religious events; however, all other activities in the public space are at a critically low level. Their level of civic participation is also low: they do somewhat follow the national news and they may vote but they are otherwise passive in terms of civic activity. Moreover, they have the lowest level of social belonging among the seven classes. Their sense of belonging to family, community, and society at large is weak and they do not have the objective prerequisite for close familial ties because they live in a one-person household. In contrast to class 1 , this class does not seem to have a compensatory mechanism for the lack of familial and other social ties.

Class 3 - low level of social embeddedness. This is the most socially isolated class. These people live in households with other family member(s) and their network of social relations is largely limited to family. They score low on every indicator of social activity. They may host guests or visit other people, attend religious practices, or interact with neighbours, but otherwise their social participation is limited. They exhibit almost no civic participation and their sense of belonging is low. Although they live with other family members and thus have someone to talk to, they seem to experience tensions with other household members more often than the other classes do, and their sense of belonging to the family, community, and society at large is the lowest out of all the classes. This fact coupled with the very low level of social and civic participation means that this class is the most at risk of social isolation, even though they do not live alone.

Table 1: Profile output for the LCA model of 7 classes

\begin{tabular}{|c|c|c|c|c|c|c|c|}
\hline \multirow{3}{*}{ Dimensions and indicators } & Class 6 & Class 1 & Class 2 & Class 4 & Class 5 & Class 7 & Class 3 \\
\hline & \multicolumn{7}{|c|}{ Class prevalence, per cent } \\
\hline & 14.8 & 14.7 & 14.0 & 22.5 & 5.6 & 12.6 & 15.9 \\
\hline $\begin{array}{l}\text { Social participation, sum of } \\
\text { indicators } 1-13\end{array}$ & 12.224 & 9.895 & 8.931 & 7.564 & 6.607 & 4.937 & 4.114 \\
\hline Hosted guests & $1.676^{8}$ & 1.425 & 1.237 & 1.282 & 1.197 & 1.018 & 0.996 \\
\hline Visited others & 1.646 & 1.548 & 1.287 & 1.169 & 1.152 & 0.885 & 0.762 \\
\hline $\begin{array}{l}\text { Participated in social eating in } \\
\text { public place }\end{array}$ & 1.227 & 0.989 & 1.141 & 0.478 & 0.922 & 0.178 & 0.208 \\
\hline $\begin{array}{l}\text { Participated in religious or } \\
\text { spiritual meeting }\end{array}$ & 0.874 & 0.773 & 0.751 & 0.748 & 0.751 & 0.592 & 0.476 \\
\hline Consumed culture & 1.110 & 0.920 & 1.025 & 0.394 & 0.773 & 0.147 & 0.163 \\
\hline Participated in arts activities & 0.707 & 0.573 & 0.577 & 0.151 & 0.328 & 0.072 & 0.041 \\
\hline Participated in sports activities & 1.124 & 0.928 & 1.054 & 0.379 & 0.702 & 0.108 & 0.191 \\
\hline
\end{tabular}




\begin{tabular}{|c|c|c|c|c|c|c|c|}
\hline Interacted with neighbours & 0.835 & 0.746 & 0.540 & 0.773 & $0.046^{* *}$ & 0.631 & 0.517 \\
\hline Interacted with friends & 0.698 & 0.570 & 0.447 & 0.409 & $0.082 * *$ & 0.204 & $0.138^{*}$ \\
\hline Interacted with children*** & 0.853 & 0.604 & $0.369 *$ & 0.771 & $0.384^{*}$ & 0.529 & $0.322^{*}$ \\
\hline Interacted with grandchildren*** & $0.694^{*}$ & $0.388^{*}$ & $0.142 *$ & 0.584 & $0.040 * *$ & $0.315^{*}$ & $0.150 *$ \\
\hline Interacted with relatives ${ }^{\star * *}$ & 0.427 & 0.302 & 0.130 & 0.245 & $0.161 * *$ & 0.219 & 0.089 \\
\hline Interacted with parent(-s)*** & $0.353 * *$ & $0.129 * *$ & $0.231 *$ & $0.181 * *$ & $0.069 * *$ & $0.039 * *$ & $0.061 * *$ \\
\hline $\begin{array}{l}\text { Civic participation, } \\
\text { sum of indicators } 14-18\end{array}$ & 4.323 & 3.726 & 3.679 & 2.899 & 2.703 & 2.192 & 2.157 \\
\hline Followed national news & 1.619 & 1.536 & 1.574 & 1.549 & 1.156 & 1.291 & 1.47 \\
\hline Voted in national elections & 0.864 & 0.817 & 0.840 & 0.741 & 0.681 & 0.582 & 0.445 \\
\hline $\begin{array}{l}\text { Provided unpaid help } \\
\text { (for non-relatives) }\end{array}$ & 0.652 & 0.536 & 0.542 & 0.333 & 0.413 & 0.161 & 0.139 \\
\hline Volunteered & 0.568 & 0.396 & 0.305 & 0.073 & 0.294 & 0.068 & 0.025 \\
\hline Undertook civic actions & 0.620 & 0.441 & 0.419 & 0.204 & 0.159 & 0.090 & 0.078 \\
\hline $\begin{array}{l}\text { Sense of belonging, } \\
\text { sum of indicators } 19-23\end{array}$ & 5.871 & 3.118 & 3.823 & 5.318 & 4.801 & 2.155 & 2.579 \\
\hline $\begin{array}{l}\text { Has a person in household } \\
\text { to talk to }\end{array}$ & 0.962 & $0.001 * *$ & 0.840 & 0.954 & 0.796 & $0.001^{* *}$ & 0.719 \\
\hline $\begin{array}{l}\text { No tensions with household } \\
\text { members }\end{array}$ & 0.788 & $0.001 * *$ & 0.495 & 0.755 & 0.731 & $0.001 * *$ & 0.489 \\
\hline Feels close to family & 1.806 & 1.403 & 1.261 & 1.727 & 1.537 & 1.009 & 0.799 \\
\hline Feels close to neighbourhood & 1.091 & 0.672 & 0.419 & 0.938 & 0.659 & 0.504 & 0.227 \\
\hline $\begin{array}{l}\text { Feels a full-fledged member } \\
\text { of society }\end{array}$ & 1.224 & 1.041 & 0.808 & 0.944 & 1.078 & 0.640 & 0.345 \\
\hline $\begin{array}{l}\text { Overall social embeddedness, } \\
\text { total sum of indicators } 1-23\end{array}$ & 22.418 & 16.739 & 16.434 & 15.782 & 14.111 & 9.284 & 8.850 \\
\hline
\end{tabular}

White cell - the level of expression (frequency or intensity) of indicator for the class is 100 per cent and more of the average for that indicator.

Light grey cell - the level of expression (frequency or intensity) of indicator for the class is 60-99 per cent of the average for that indicator.

Grey cell - the level of expression (frequency or intensity) of indicator for the class is less than 60 per cent of the average for that indicator.

* Some but no more than half of members of the class (0.202-0.496) reported that the relationships in question are not applicable in their case.

** More than half of members of the class (0.531-0.998) reported that the relationships in question are not applicable in their case.

$* * *$ Respondent interacted with named persons living outside his/her household.

${ }^{8}$ For dichotomous variables, the maximum possible value is ' 1 '. The researchers, having available differentiated data on the intensity (frequency and strength) of activities and feelings, sought to purposefully highlight the relief of the levels of engagement in social relations. Thus, the role of the highest intensity indicators in the analysis was strengthened - they were multiplied by a coefficient of ' 2 ' during coding. Therefore, the values in cells exceeding ' 1 ' means the exceptional intensity of activity or feeling within the specific class. 


\section{The covariates of socially embedded classes}

We also looked at the covariates that could provide a more detailed understanding of the characteristics that may predict or are linked to belonging to each of the seven classes of social embeddedness. We were able to identify some of the objective prerequisites that may define different levels of social embeddedness. We specifically examined whether we could trace gender differences among the classes. We found that gender can have a statistically significant effect on the chances of belonging to class 1 and class 3. Otherwise, gender was significant only in separate cases of class comparisons.

Below we highlight the main statistically significant covariates for each class. Table 2 in the Annex provides a detailed inter-class comparison in relation to the covariates.

Gender. In general, there is no clear pattern to indicate that men or women have different chances of being socially embedded in their later lives. However, we observed statistically significant gender effects in two classes: class 1, which was characterised by a high level of social embeddedness, and class 3, which, on the contrary, had the lowest level of social embeddedness. There are more women in class 1 than in class 2, class 5, class 7, and class 3 . Whereas in class 3 there are more men compared to classes $6,1,4$, and 5. Also, gender differences can be observed when other classes with moderate to low levels of social embeddedness are compared to class 6 and class 1 (both of which have high levels of social embeddedness). Men are more likely to belong to class 4 than to classes 6 and 1, to class 2 than to class 1 , and to class 7 than to class 1 . Therefore, data analysis allows us to presume that men at an older age may be at a slightly higher risk of experiencing lower levels of social embeddedness than women.

Other potential predictors. We additionally examined the covariates that can potentially predict the chance (or risk) of an older person experiencing a higher or lower level of social embeddedness. We focused on the subjective economic status of a household, subjective health status, educational attainment, participation in education, household size (number of people living together in a household), marital status, knowledge of titular language (the official language of a country of residence), and employment status. We provide the most observable statistically significant covariates for each class and list them in the order of decreasing levels of social embeddedness (for details see Table 2 in the Annex).

Class 6 - The chance of experiencing a high level of social embeddedness is better for older people who are still employed and / or in training, have higher educational attainment, have a better subjective assessment of their health, and live in a larger household.

Class 1 - As we discussed above, being a female is an apparent predictor of belonging to this class; also, members of this class more often live alone than members 
of other classes do; their educational attainment is to a statistically significant degree higher than that of members of class 7 and class 3.

Class 2 - One of the key predictors for this class is being employed (statistically significant compared to class 1, 4, 7 and 3), and members of this class tend to live in smaller households than those in classes 3,4 , and 6 , and their subjective health is better that that of the least socially embedded classes 7 and 3 .

Class 4 - Members of this class tend to have lower educational attainment, are less involved in training and employment (except when compared to class 3 ), and live in bigger households.

Class 5 - This class stands out for the lower level of the command of the titular language among its members. It is a proxy variable for residence status and being born in the given country. Therefore, we can predict that residents of foreign descent (potentially without citizenship status) tend more often to belong to this class. They live in bigger households, tend to have a higher level of educational attainment (compared to those in classes 4, 7, and 3), and experience more financial difficulties (compared to those in classes 6, 2 and 4).

Class 7 - These people tend to live in smaller households, have a lower level of educational attainment, are not employed, and have a lower level of subjective health.

Class 3 - As already observed, men tend to belong to this class more often. Members of this class also have a lower level of subjective health and lower educational attainment, are not employed or in training, and live in bigger households.

Social trust. Trust is an important social resource; in-group trust (or trust in those who are close and familiar) is more universal, whereas out-group trust (or trust in those who are strangers to and are different from us) has been found to reflect human empowerment when dependency on in-group relations lowers and outgroup cooperation or engagement expands (Delhey, Welzel 2012; Crepaz et al. 2017). Social trust is a complex phenomenon, so it can be interpreted as both an input and an output variable. Therefore, we looked at how the two forms of social trust could be linked to the level of social embeddedness. We found some interesting though not unexpected patterns in our results. In the overall sample of respondents aged 50+, most respondents (close to 90\%) expressed in-group trust. However, when it came to out-group trust, around one-quarter of the respondents did not identify their level of trust (chose answer option "don't know / hard to say") and another 40 to 50\% of them did not trust out-group categories of people very much or at all. Thus, it is not surprising that there are no significant out-group trust differences between the classes except for class 4. Being primarily embedded in familial social relations (which seems are supportive to them), the members of this class have significantly lower levels of out-group trust, which is also reflected in their low level of civic participation. Their in-group trust levels are significantly higher than those in other classes. Class 
6 demonstrates statistically significantly stronger in-group trust than classes 2, 5, 7, and 3. Class 2, on the contrary, has lower levels of in-group trust than any other class, which reflects their detachment from familial relationships. The least socially embedded class, which is 3 , has lower levels of in-group trust than the most socially embedded one, class 6, and also lower than class 4 (though it is higher than class 7). Class 7 also has lower in-group trust than classes 6, 1, and 4.

Subjective wellbeing. We presume subjective wellbeing to be an output covariate and examine whether a higher or lower level of social embeddedness is linked to higher or lower subjective wellbeing. Our data analysis confirms that subjective wellbeing is significantly related to social embeddedness. Its effect is especially apparent in the classes at the marginal end of the continuum of social embeddedness. In class 6 , with the highest level of social embeddedness, the levels of subjective wellbeing are statistically significantly higher than in most other classes with lower levels of social embeddedness $(2,5,7$, and 3$)$. In the class with a high level of social embeddedness (class 1), the levels of subjective wellbeing are significantly higher than the less socially embedded classes $(2,7$, and 3$)$ as well. Conversely, the level of subjective wellbeing is statistically significantly lower among members of the classes with the lowest levels of social embeddedness. For older people who belong to class 3, subjective wellbeing is lower than it is in classes 6, 1, 4, and 5; in class 7 subjective wellbeing is lower than it is in classes 6,1 , and 4 .

There are two more classes that have an interesting pattern of linkage between social embeddedness and subjective wellbeing. One of the classes with a higher level of social embeddedness (class 2 ) has a statistically significantly lower level of subjective wellbeing compared to classes $6,1,4$, and 5 (its subjective wellbeing is at the level of the least socially embedded classes, 7 and 3). Subjective wellbeing in class 4 does not differ from that in the most embedded classes, 6 and 1 (and also the partially embedded class 5), but it is significantly higher than in classes 2, 7, and 3. Comparing the profiles of class 2 and class 4 we can see that they differ in the closeness of their familial ties; thus, it is possible to presume that having wider and better familial ties produces higher overall subjective well-being even when the overall social embeddedness is lower.

\section{Discussion and conclusion}

The LCA method helped to identify subgroups of the older population according to the level of their embeddedness in social relationships (conceptualised via dimensions of social participation, civic participation, and sense of belonging) and to examine patterns of social embeddedness by gender. The study revealed that people aged 50 and over residing in the Baltics are consistently dispersed across the social 
embeddedness continuum. The two extremes of this continuum are represented by rich and diverse social and civic participation and a strong sense of belonging at one end and scarcity, one-sided participation, and a low sense of belonging at the other end. Intermediate positions on this continuum consist of various combinations of the measured dimensions. Some subgroups (class 2 ) have relatively high levels of social and civic participation, but this does not result in a correspondingly high sense of belonging. Other subgroups are relatively less socially and civically involved, and their social participation also tends to be concentrated in one area (community or family), but their sense of belonging varies - in some cases (classes 4 and 5) it does not suffer (it is quite strong), while in others (classes 7 and 3 ) it is weak.

The various combinations of different dimensions that constitute overall social embeddedness that we observed here allowed us to summarise that not only the breadth and frequency of social relations but also their quality is vital for stronger social embeddedness. In line with this, we observed that if a person has connections but there is lack of trust, this will be manifested as weaker social embeddedness.

The patterns of older men's and women's social embeddedness confirm the gender similarity hypothesis (Hyde 2005) in classes 2, 4, 5, and 7. Women's and men's probability of belonging to these classes is similar and we did not detect any statistically significant differences. We found gender differences in two subgroups (classes 1 and 3) of older adults residing in the Baltics. These classes are located at opposite ends of the social embeddedness scale. Older women dominantly belong to class 1, which is characterised by the high level of social embeddedness. In contrast, older men much more often than women of the same age tend to be members of class 3, which includes older people with the lowest indicators of embeddedness in social relations. Class 6 , which occupies the position at the very top of the scale (the highest indicators of social embeddedness), is also slightly more predominated by women (compared to classes 4 and 3). When everything is considered, this means that older women tend to be slightly more concentrated at the top of the social embeddedness scale, while their male counterparts tend to be located somewhat more often in the lower segments of the scale. This is, however, a rather surprising discovery. To now older women have more often been described in the literature as vulnerable (Arber, Cooper 1999; Inglehart, 2002; Saito et al. 2012). Nevertheless, our study revealed that older men predominate among those most poorly embedded in social relationships. They are in a critical situation because it seems that many of them are unable to go out to socialise (except to visit neighbours or attend church), and their social networks outside the household and their interactions with them are very limited. Most of them do not live alone - they are surrounded by family member who live in the same household, but these relationships appear to be unsupportive and do not create a sense of belonging to the family. One explanation for the predominance 
of frail older men in unsupportive households could be provided by the findings of Carvalho (2019), who observed gender differences in the preferred types of longterm care. Carvalho (2019) argues that older men were more likely to choose a home setting with informal, unprofessional caregiving, even when their level of disability increased; women by contrast more often chose help from professionals, sheltered homes, or institutional care.

Our study of social embeddedness among the 50+ population implicitly revealed (through covariates) and confirmed the insights of other researchers (Walsh et al. 2017; Regenmortel et al. 2016; Levitas et al. 2007; Burchardt et al. 2009) that an individual's involvement in the labour market plays a significant role in his or her social embeddedness. Both working older men and women tend to end up in classes with a higher level of social embeddedness than people who are not working. It seems that withdrawal from the labour market is usually associated with a descent in the hierarchy of social-embeddedness levels. However, an exception was recorded in our survey. This is class 1 (accounting for one-seventh or 15\% of the sample), where the decisive majority is made up of women who live alone, are not working, and have a higher than disadvantaged classes 7 and 3 level of educational attainment. Members of class 1 were able to maintain a surprisingly high level of social embeddedness and thus share a high position in the social embeddedness continuum together with classes 6 and 2 (both of them are populated by employed older adults). This shows that not working people may have constellations of social networks, an intensity of interactions with others, and a sense of belonging, all of which creates an even stronger embeddedness in social relationships than the embeddedness of people who are working (class 1 compared to class 2).

Although, overall, the respondents in our sample tended to demonstrate high level of in-group trust, the regression analysis revealed that both a lack of social ties and a lower perceived quality of existing social ties weakens the basis for forming trust even within a circle of familiar people. This, in turn, can lead to further exclusion from social relationships, whereas higher social embeddedness is accompanied by a stronger tendency towards in-group trust. Even though we did not see any clear pattern to indicate that social embeddedness enhances the level of out-group trust (as it is also less characteristic for the sample as a whole), we can see that social embeddedness that is highly dependent on familial ties may prevent the formation of out-group trust and may thus reduce the likelihood of a person engaging with wider social circles.

The study showed that the model we developed was useful for providing a more nuanced picture of social embeddedness, identifying subgroups of older people according to their level of embeddedness in social relations, and understanding their heterogeneity. The study also filled in the gap in knowledge about the gendered 
risk of old-age exclusion from social relationships in one Eastern European region. However, some limitations should be mentioned. We applied the LCA to the overall survey sample; however, it would be reasonable to further explore LCA models separately for men and women and for each country under study to identify even more detailed patterns of social embeddedness and risks of exclusion from social relationships. Based on a multidimensional conceptualisation of social embeddedness, we constructed a measurement tool that covers all three of its dimensions. However, we believe that it is important to further refine the conceptual clarity of social embeddedness, its composite parts as well as its relationship to the current variety of parallel concepts that exist, such as community participation, social inclusion, social connectedness, social integration, social capital, social well-being, community inclusion, social acceptance, etc.

\section{References}

Antonucci, T. C. 1990. Social Supports and Social Relationships. Pp. 205-226 in Binstock, R. H., L. K. George (eds.). The Handbook of Aging and the Social Sciences. 3rd ed. Orlando, FL: Academic Press.

Arber, S., H. Cooper. 1999. Gender Differences in Health in Later Life: The New Paradox? Social Science \& Medicine 48 (1): 61-76.

Ashida, S., C. A. Heaney. 2008. Differential Associations of Social Support and Social Connectedness With Structural Features of Social Networks and the Health Status of Older Adults. Journal of Aging and Health 20 (7): 872-893.

Barnes, M., A. G. Blom, K. Cox, C. Lessof, A. Walker. 2006. The Social Exclusion of Older People: Evidence from the First Wave of the English Longitudinal Study of Ageing (ELSA). London: Office of the Deputy Prime Minister.

Baumgartner, J. N., J. K. Burns. 2014. Measuring Social Inclusion-A Key Outcome in Global Mental Health. International Journal of Epidemiology 43 (2): 354-364.

Becker, C., I. Kirchmaier, S. T. Trautmann. 2019. Marriage, Parenthood and Social Network: Subjective Well-Being and Mental Health in Old Age. PloS one 14 (7): e0218704.

Berkman, L. F., T. Glass, I. Brisette, T. E. Seeman. 2000. From Social Integration to Health: Durkheim in the New Millennium. Social Science and Medicine 51: 843-857.

Bukov, A., I. Maas, T. Lampert. 2002. Social Participation in Very Old Age: Cross-Sectional and Longitudinal Findings from BASE. The Journals of Gerontology Series B: Psychological Sciences and Social Sciences 57 (6): 510-517.

Burchardt, T., J. Le Grand. 2002. Degrees of Exclusion: Developing a Dynamic, Multidimensional. Pp. 30-43 in Hills, J., J. Le Grand, D. Piachaud (eds.). Understanding Social Exclusion. Oxford: Oxford University Press.

Burholt, V., B. Winter, M. Aartsen, et al. 2020. A Critical Review and Development of a Conceptual Model of Exclusion from Social Relations for Older People. European Journal of Ageing 17: 3-19, https://doi.org/10.1007/s10433-019-00506-0.

Carvalho, N., L. Meylan, J. M. Blanco, S. Fustinoni, N. Abolhassani, B. Santos-Eggimann. 


\section{NV STATI / ARTICLES}

2019. Gender Differences Regarding Opinions on Long-Term Care Arrangements:

A Study of Community-Dwelling Older Adults. Archives of Gerontology and Geriatrics 83: 195-203.

Collins, L. M., S. T. Lanza. 2010. Latent Class and Latent Transition Analysis: With Applications in the Social, Behavioral, and Health Sciences. New York: Wiley.

Cordier, R., B. Milbourn, R. Martin, A. Buchanan, D. Chung, R. Speyer, 2017. A Systematic Review Evaluating the Psychometric Properties of Measures of Social Inclusion. PLoS One 12 (6): e0179109, https://doi.org/10.1371/journal.pone.0179109.

Crepaz, M. M. L., K. Bodnaruk Jazayeri, J. Polk. 2017. What's Trust Got to Do with It? The Effects of In Group and Out Group Trust on Conventional and Unconventional Political Participation. Social Science Quarterly 98 (17): 261-281, https://doi.org/10.1111/ ssqu.12271.

Crisp, B. R. 2010. Belonging, Connectedness and Social Exclusion. Journal of Social Inclusion 1 (2): 123-132.

Delhey, J., C. Welzel. 2012. Generalizing Trust: How Outgroup-Trust Grows Beyond IngroupTrust. World Values Research 5 (3): 46-69, https://doi.org/10.2139/ssrn.2390636.

Dijkers, M. P. 2010. Issues in the Conceptualization and Measurement of Participation: An Overview. Archives of Physical Medicine and Rehabilitation 91 (9): S5-S16.

Durkheim, E. (1912) 1995. The Elementary Forms of the Religious Life. New York: The Free Press.

European Values Study. 2018. European Values Study - EVS 2017. Master Questionnaire. [Questionnaire]. Retrieved 29/6/2021 (https://europeanvaluesstudy.eu/methodologydata-documentation/survey-2017/pre-release-evs-2017/documentation-survey-2017/).

Gyasi, R. M., D. R. Phillips, K. Abass. 2019. Social Support Networks and Psychological Wellbeing in Community-Dwelling Older Ghanaian Cohorts. International Psychogeriatrics 31 (7): 1047-1057.

Hagerty, B. M., J. Lynch-Sauer, K. L. Patusky, M. Bouwsema, P. Collier. 1992. Sense of Belonging: A Vital Mental Health Concept. Archives of Psychiatric Nursing 6 (3): 172-177. Hyde, J. S. 2005. The Gender Similarities Hypothesis. American Psychologist 60 (6): $581-$ 592, https://doi.org/10.1037/0003-066X.60.6.581.

Inglehart, R. 2002. Gender, Aging, and Subjective Well-Being. International Journal of Comparative Sociology 43 (3-5): 391-408, https://doi. org/10.1177/002071520204300309.

Joshanloo, M., V. Jovanović, T. Taylor. 2019. A Multidimensional Understanding of Prosperity and Well-Being at Country Level: Data-Driven Explorations. PloS one 14 (10): e0223221.

Kairys A., A. Bagdonas, A. Liniauskaitè, V. Pakalniškienè. 2013. LPGS: Lietuviškoji psichologinés gerovès skalè. Vilnius: VU I-kla.

Labonté, R. N., A. Hadi, X. E. Kauffmann. 2012. Indicators of Social Exclusion and Inclusion: A Critical and Comparative Analysis of the Literature. Ottawa: Population Health Improvement Research Network.

Lee, R. M., S. B. Robbins. 1995. Measuring Belongingness: The Social Connectedness and the Social Assurance Scales. Journal of Counselling Psychology 42: 232-241. 
Lee, R. M, M. Draper, S. Lee. 2001. Social Connectedness, Dysfunctional Interpersonal Behaviors, and Psychological Distress: Testing a Mediator Model. Journal of Counselling Psychology 48: 310-318.

Levasseur, M., J. Desrosiers, D. St-Cyr Tribble. 2008. Subjective Quality-of-Life Predictors for Older Adults with Physical Disabilities. American Journal of Physical Medicine \& Rehabilitation 87 (10): 830-841.

Levasseur, M., L. Richard, L. Gauvin, É. Raymond. 2010. Inventory and Analysis of Definitions of Social Participation Found in the Aging Literature: Proposed Taxonomy of Social Activities. Social Science and Medicine 71 (12): 2141-2149.

Levitas, R., C. Pantazis, E. Fahmy, D. Gordon, E. Lloyd-Reichling, D. Patsios. 2007. The Multi-Dimensional Analysis of Social Exclusion. Report funded by the Department for Communities and Local Government (DCLG). Retrieved 2/7/2021 (https://repository.uel. ac.uk/).

Lewin, K. 1951. Field Theory in Social Science. New York, Harper- Row.

Maes, M., P. Qualter, J. Vanhalst, W. Van den Noortgate, L. Goossens. 2019. Gender Differences in Loneliness across the Lifespan: A Meta Analysis. European Journal of Personality 33 (6): 642-654.

Maslow, A. H. 1954. Motivation and Personality. New York: Harper and Row.

Mikulionienè, S., Rapolienè, G., Valavičienè, N. 2018. Vyresnio amžiaus žmonès, gyvenimas po vieną ir socialinè atskirtis. Vilnius: LSTC.

Palmberger, M. 2017. Social Ties and Embeddedness in Old Age: Older Turkish Labour Migrants in Vienna. Journal of Ethnic and Migration Studies 432: 235-249.

Park, R.E. 1924. The Concept of Social Distance. Journal of Applied Sociology 8: 339-344.

Park, R.E. 1926. The Concept of Position in Sociology. Papers and Proceedings of the American Sociological Society 20: 1-14.

Pinquart, M., S. Sörensen. 2000. Influences of Socio-Economic Status, Social Networks and Competence on Subjective Well-Being in Later Life: A Meta-Analysis. Psychology and Ageing 15 (2): 187-224, doi:10.1037/0882-7974.15.2.187.

Piškur, B., R. Daniëls, M. J. Jongmans, M. Ketelaar, R. J. Smeets, M. Norton, M., A. J. Beurskens. 2014. Participation and Social Participation: Are They Distinct Concepts? Clinical Rehabilitation 28 (3): 211-220.

Regenmortel Van, S., L. De Donder, S. Dury, A. S. Smetcoren, N. De Witte, D. Verté. 2016. Social Exclusion in Later Life: A Systematic Review of the Literature. Journal of Population Ageing 9 (4): 315-344.

Saito, M., N. Kondo, K. Kondo, T. Ojima, H. Hirai. 2012. Gender Differences on the Impacts of Social Exclusion on Mortality among Older Japanese: AGES Cohort Study. Social Science \& Medicine 75 (5): 940-945.

Schafer, J. L., J. Kang. 2013. LCCA Package for R Users' Guide (Version 1.1.0). University Park: The Methodology Center, Penn State.

Scharf, T., C. Phillipson, A. E. Smith. 2005. Social Exclusion of Older People in Deprived Urban Communities of England. European Journal of Ageing 22: 76-87.

Taket, A., B. R. Crisp, A. Nevill, G. Lamaro, M. Graham, S. Barter-Godfrey (eds.). 2009. Theorising Social Exclusion. Abingdon: Routledge. 


\section{STATI / ARTICLES}

UNECE [United Nations Economic Commission for Europe]. 2016. Recommendations on Ageing-Related Statistics. Prepared by the Task Force on Ageing-related Statistics. New York and Geneva: United Nations.

Walsh, K., T. Scharf, N. Keating. 2017. Social Exclusion of Older Persons: A Scoping Review and Conceptual Framework. European Journal of Ageing 14 (1): 81-98.

Ward, P., K. Walsh, T. Scharf. 2014. Measuring Old-Age Social Exclusion in a Cross-Border Context: Findings of a Comparative Secondary Analysis in Ireland and Northern Ireland. Galway: Irish Centre for Social Gerontology.

Wenger, G. C., P. A. Dykstra, T. Melkas, K. C. Knipscheer. 2007. Social Embeddedness and Late-Life Parenthood: Community Activity, Close Ties, and Support Networks. Journal of Family Issues 28 (11): 1419-1456.

Yanicki, S. M., K. E. Kushner, L. Reutter. 2015. Social Inclusion/Exclusion as Matters of Social (In) Justice: A Call for Nursing Action. Nursing Inquiry 22 (2): 121-133.

Ye, L., X. Zhang. 2019. Social Network Types and Health among Older Adults in Rural China: The Mediating Role of Social Support. International Journal of Environmental Research and Public Health 16 (3): 410 (1-29).

(c) BY-NC Sarmitè Mikulionienė, Inga Gaižauskaitè, Vaidas Morkevičius, 2021.

(c) BY-NC Institute of Sociology of the Czech Academy of Sciences, 2021.

Dr. Sarmitè Mikulioniene is a senior researcher at the Institute of Sociology of the Lithuanian Centre for Social Sciences (Lithuania). Her main research interests are the demography of population ageing, ageing policy, ageism, social exclusion and loneliness, intergenerational relationships, and lifelong learning. Contact e-mail: mikulioniene@lsct.lt.

Inga Gaižauskaitè is a junior researcher at the Institute of Sociology of the Lithuanian Centre for Social Sciences (Lithuania). Her main research interests include democratisation, social and political trust, intergenerational relationships, and developments in social research methodology. Contact e-mail: inga.gaizauskaite@lstc.lt.

Dr. Vaidas Morkevičius is a senior researcher at the Institute of Social Sciences, Arts and Humanities of Kaunas University of Technology (Lithuania). His latest research is on interwar socio-economic history and social structuration of the Baltic states. Contact e-mail: vaidas. morkevicius@ktu.It.

\section{Annex}

Table 1: Criteria for the appropriate LC model selection

\begin{tabular}{llllll}
\hline $\begin{array}{l}\text { Number } \\
\text { of Classes }\end{array}$ & Loglikelihood & $\begin{array}{l}\text { Loglikelihood }+ \\
\text { penalty }\end{array}$ & $\begin{array}{l}-2^{*} \\
\text { Loglikelihood }\end{array}$ & AIC & BIC \\
\hline 2 & -37850.53544 & -37916.87273 & 75701.07089 & 75879.07089 & 76378.21622 \\
\hline 3 & -37337.97401 & -37441.75259 & 74675.94801 & 74943.94801 & 75695.47019 \\
\hline
\end{tabular}




\begin{tabular}{llllll}
\hline 4 & -36597.98966 & -36748.61654 & 73195.97932 & 73553.97932 & 74557.87835 \\
\hline 5 & -36154.60189 & -36348.34016 & 72309.20379 & 72757.20379 & 74013.47967 \\
\hline 6 & -35830.65526 & -36062.50395 & 71661.31052 & 72199.31052 & 73707.96326 \\
\hline $\mathbf{7}$ & -35603.28210 & -35875.35017 & 71206.56420 & 71834.56420 & $\mathbf{7 3 5 9 5 . 5 9 3 7 8}$ \\
\hline 8 & -35453.63934 & -35765.77166 & 70907.27868 & 71625.27868 & 73638.68511 \\
\hline 9 & -35309.03997 & -35663.83316 & 70618.07994 & 71426.07994 & 73691.86323 \\
\hline 10 & -35125.40691 & -35522.95818 & 70250.81381 & 71148.81381 & 73666.97395 \\
\hline
\end{tabular}

Table 2: Multinomial regression analysis results

\begin{tabular}{|c|c|c|c|c|c|c|c|}
\hline Class & 6 & 1 & 2 & 4 & 5 & 7 & 3 \\
\hline $66^{*}$ & & $\begin{array}{l}\uparrow * * 2 \text { pers } * * * \\
H H^{* * * *} \\
\uparrow 3+\text { pers } H H\end{array}$ & $\begin{array}{l}{ }_{\uparrow} 2 \text { pers HH } \\
\uparrow 3+\text { pers HH } \\
\uparrow \text { Ing trust } \\
\uparrow \text { SWB }\end{array}$ & $\begin{array}{l}\text { } \uparrow \text { Females } \\
\uparrow \text { SHealth } \\
\uparrow \text { Adv edu } \\
\uparrow \text { Higher edu } \\
\uparrow \text { Language } \\
\uparrow \text { Employed } \\
\uparrow \text { In training } \\
\uparrow \text { Outg trust }\end{array}$ & $\begin{array}{l}\text { 个 Econ strain } \\
\uparrow \text { Language } \\
\uparrow \text { In training } \\
\uparrow \text { Ing trust } \\
\uparrow \text { SWB }\end{array}$ & $\begin{array}{l}\text { 个 Higher edu } \\
\uparrow 2 \text { pers } \mathrm{HH} \\
\uparrow 3+\text { pers } \mathrm{HH} \\
\uparrow \text { Employed } \\
\uparrow \text { In training } \\
\uparrow \text { Ing trust } \\
\uparrow \text { SWB }\end{array}$ & $\begin{array}{l}\uparrow \text { Females } \\
\uparrow \text { SHealth } \\
\uparrow \text { Adv edu } \\
\uparrow \text { Higher edu } \\
\uparrow \text { Married } \\
\uparrow \text { Language } \\
\uparrow \text { Employed } \\
\uparrow \text { In training } \\
\uparrow \text { Ing trust } \\
\uparrow \text { SWB }\end{array}$ \\
\hline 1 & $\begin{array}{l}\downarrow 2 \text { pers } \mathrm{HH} \\
\downarrow 3+\text { pers } \mathrm{HH}\end{array}$ & & $\begin{array}{l}\uparrow \text { Females } \\
\downarrow 2 \text { pers } \mathrm{HH} \\
\downarrow 3 \text { pers HH } \\
\downarrow \text { Single } \\
\downarrow \text { Employed } \\
\uparrow \text { Ing trust } \\
\uparrow \text { SWB }\end{array}$ & $\begin{array}{l}\text { 个 Females } \\
\downarrow \mathbf{2} \text { pers } \mathbf{H H} \\
\downarrow \mathbf{3}+\text { pers } \mathbf{H H} \\
\uparrow \text { In training } \\
\uparrow \text { Outg trust }\end{array}$ & $\begin{array}{l}\downarrow \mathbf{2} \text { pers } \mathbf{H H} \\
\downarrow \mathbf{3}+\text { pers } \mathbf{H H} \\
\downarrow \text { Single } \\
\uparrow \text { Language }\end{array}$ & $\begin{array}{l}\text { 个 Females } \\
\uparrow \text { Adv edu } \\
\uparrow \text { Higher edu } \\
\uparrow \text { Employed } \\
\uparrow \text { Ing trust } \\
\uparrow \text { SWB }\end{array}$ & $\begin{array}{l}\text { 个 Females } \\
\uparrow \text { Adv edu } \\
\uparrow \text { Higher edu } \\
\downarrow 2 \text { pers HH } \\
\downarrow 3+\text { pers HH } \\
\uparrow \text { In training } \\
\uparrow \text { SWB }\end{array}$ \\
\hline . & $\begin{array}{l}\downarrow 2 \text { pers } \mathrm{HH} \\
\downarrow 3+\text { pers } \mathrm{HH} \\
\downarrow \text { Ing trust } \\
\downarrow \text { SWB } \\
\end{array}$ & $\begin{array}{l}\downarrow \text { Females } \\
\uparrow \mathbf{2} \text { pers } \mathrm{HH} \\
\uparrow 3+\text { pers } \mathrm{HH} \\
\uparrow \text { Single } \\
\uparrow \text { Employed } \\
\downarrow \text { Ing trust } \\
\downarrow \text { SWB }\end{array}$ & & $\begin{array}{l}\uparrow \text { Higher edu } \\
\downarrow \mathbf{2} \text { pers } \mathrm{HH} \\
\downarrow \mathbf{3} \text { + pers HH } \\
\uparrow \text { Employed } \\
\uparrow \text { In training } \\
\downarrow \text { Ing trust } \\
\uparrow \text { Outg trust } \\
\downarrow \text { sWB }\end{array}$ & $\begin{array}{l}\downarrow \text { Econ strain } \\
\downarrow 2 \text { pers HH } \\
\downarrow \mathbf{3} \text { + pers HH } \\
\uparrow \text { Language } \\
\downarrow \text { Ing trust } \\
\downarrow \text { sWB }\end{array}$ & $\begin{array}{l}\text { } \uparrow \text { SHealth } \\
\uparrow \text { Higher edu } \\
\uparrow 2 \text { pers } \mathrm{HH} \\
\uparrow 3 \text { + pers } \mathrm{HH} \\
\uparrow \text { Single } \\
\uparrow \text { Employed } \\
\uparrow \text { In training } \\
\downarrow \text { Ing trust }\end{array}$ & $\begin{array}{l}\text { } \uparrow \text { Females } \\
\uparrow \text { SHealth } \\
\uparrow \text { Higher edu } \\
\downarrow 2 \text { pers HH } \\
\downarrow 3+\text { pers HH } \\
\uparrow \text { Employed } \\
\uparrow \text { In training } \\
\downarrow \text { Ing trust }\end{array}$ \\
\hline . & $\begin{array}{l}\downarrow \text { Females } \\
\downarrow \text { SHealth } \\
\downarrow \text { Adv edu } \\
\downarrow \text { Higher edu } \\
\downarrow \text { Language } \\
\downarrow \text { Employed } \\
\downarrow \text { In training } \\
\uparrow \text { Ing trust } \\
\downarrow \text { Outg trust }\end{array}$ & $\begin{array}{l}\downarrow \text { Females } \\
\uparrow \mathbf{2} \text { pers } \mathbf{H H} \\
\uparrow \mathbf{3}+\text { pers HH } \\
\downarrow \text { In training } \\
\downarrow \text { Outg trust }\end{array}$ & $\begin{array}{l}\downarrow \text { Higher edu } \\
\uparrow \mathbf{2} \text { pers HH } \\
\uparrow \mathbf{3} \text { + pers HH } \\
\downarrow \text { Employed } \\
\downarrow \text { In training } \\
\uparrow \text { Ing trust } \\
\downarrow \text { Outg trust } \\
\uparrow \text { SWB }\end{array}$ & & $\begin{array}{l}\downarrow \text { Econ strain } \\
\downarrow \text { Adv edu } \\
\downarrow \text { Higher edu } \\
\uparrow \text { Language } \\
\downarrow \text { Employed } \\
\uparrow \text { Ing trust } \\
\downarrow \text { Outg trust }\end{array}$ & $\begin{array}{l}\uparrow 2 \text { pers } \mathrm{HH} \\
\uparrow 3+\text { pers } \mathrm{HH} \\
\uparrow \text { Ing trust } \\
\uparrow \mathrm{SWB}\end{array}$ & $\begin{array}{l}\text { 个 Females } \\
\uparrow \text { SHealth } \\
\uparrow \text { Higher edu } \\
\uparrow \text { Married } \\
\uparrow \text { Employed } \\
\uparrow \text { In training } \\
\uparrow \text { Ing trust } \\
\uparrow \text { SWB }\end{array}$ \\
\hline
\end{tabular}




\begin{tabular}{|c|c|c|c|c|c|c|c|}
\hline 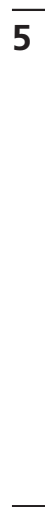 & $\begin{array}{l}\uparrow \text { Econ strain } \\
\uparrow 2 \text { pers HH } \\
\downarrow \text { Language } \\
\downarrow \text { In training } \\
\downarrow \text { Ing trust } \\
\downarrow \text { SWB }\end{array}$ & $\begin{array}{l}\uparrow 2 \text { pers } \mathbf{H H} \\
\uparrow 3 \text { + pers } \mathbf{H H} \\
\uparrow \text { Single } \\
\downarrow \text { Language }\end{array}$ & $\begin{array}{l}\uparrow \text { Econ strain } \\
\uparrow \mathbf{2} \text { pers } \mathbf{H H} \\
\uparrow \mathbf{3 + \text { pers }} \mathbf{H H} \\
\downarrow \text { Language } \\
\uparrow \text { Ing trust } \\
\uparrow \text { SWB }\end{array}$ & $\begin{array}{l}\uparrow \text { Econ strain } \\
\uparrow \text { Adv edu } \\
\uparrow \text { Higher edu } \\
\downarrow \text { Language } \\
\uparrow \text { Employed } \\
\downarrow \text { Ing trust } \\
\uparrow \text { Outg trust }\end{array}$ & & $\begin{array}{l}\uparrow \text { Higher edu } \\
\uparrow \mathbf{2} \text { pers } \mathbf{H H} \\
\uparrow \mathbf{3 + \text { pers }} \mathbf{H H} \\
\uparrow \text { Single } \\
\downarrow \text { Language } \\
\uparrow \text { Employed }\end{array}$ & $\begin{array}{l}\uparrow \text { Females } \\
\uparrow \text { SHealth } \\
\uparrow \text { Adv edu } \\
\uparrow \text { Higher edu } \\
\uparrow \text { Single } \\
\uparrow \text { Married } \\
\downarrow \text { Language } \\
\uparrow \text { Employed } \\
\uparrow \text { In training } \\
\uparrow \text { SWB }\end{array}$ \\
\hline 7 & $\begin{array}{l}\downarrow \text { Higher edu } \\
\downarrow \mathbf{2} \text { pers HH } \\
\downarrow \text { 3+ pers HH } \\
\downarrow \text { Employed } \\
\downarrow \text { In training } \\
\downarrow \text { Ing trust } \\
\downarrow \text { sWB }\end{array}$ & $\begin{array}{l}\downarrow \text { Females } \\
\downarrow \text { Adv edu } \\
\downarrow \text { Higher edu } \\
\downarrow \text { Employed } \\
\downarrow \text { In training } \\
\downarrow \text { Ing trust } \\
\downarrow \text { SWB }\end{array}$ & $\begin{array}{l}\downarrow \text { SHealth } \\
\downarrow \text { Higher edu } \\
\downarrow 2 \text { pers } \mathrm{HH} \\
\downarrow 3 \text { pers } \mathrm{HH} \\
\downarrow \text { Single } \\
\downarrow \text { Employed } \\
\downarrow \text { In training } \\
\uparrow \text { Ing trust }\end{array}$ & $\begin{array}{l}\downarrow 2 \text { pers } \mathrm{HH} \\
\downarrow 3+\text { pers } \mathrm{HH} \\
\downarrow \text { Ing trust } \\
\downarrow \text { SWB }\end{array}$ & $\begin{array}{l}\downarrow \text { Higher edu } \\
\downarrow \mathbf{2} \text { pers } \mathbf{H H} \\
\downarrow \mathbf{3} \text { pers } \mathbf{H H} \\
\downarrow \text { Single } \\
\uparrow \text { Language } \\
\downarrow \text { Employed }\end{array}$ & & $\begin{array}{l}\downarrow 2 \text { pers } \mathrm{HH} \\
\downarrow 3+\text { pers } \mathrm{HH}\end{array}$ \\
\hline & $\begin{array}{l}\downarrow \text { Females } \\
\downarrow \text { SHealth } \\
\downarrow \text { Adv edu } \\
\downarrow \text { Higher edu } \\
\downarrow \text { Married } \\
\downarrow \text { Language } \\
\downarrow \text { Employed } \\
\downarrow \text { In training } \\
\downarrow \text { Ing trust } \\
\downarrow \text { SWB }\end{array}$ & $\begin{array}{l}\downarrow \text { Females } \\
\downarrow \text { Adv edu } \\
\downarrow \text { Higher edu } \\
\uparrow 2 \text { pers HH } \\
\uparrow 3+\text { pers HH } \\
\downarrow \text { In training } \\
\downarrow \text { sWB }\end{array}$ & $\begin{array}{l}\downarrow \text { Females } \\
\downarrow \text { SHealth } \\
\downarrow \text { Higher edu } \\
\uparrow \mathbf{2} \text { pers HH } \\
\uparrow \mathbf{3}+\text { pers HH } \\
\downarrow \text { Employed } \\
\downarrow \text { In training } \\
\uparrow \text { Ing trust }\end{array}$ & $\begin{array}{l}\downarrow \text { Females } \\
\downarrow \text { SHealth } \\
\downarrow \text { Higher edu } \\
\downarrow \text { Married } \\
\downarrow \text { Employed } \\
\downarrow \text { In training } \\
\downarrow \text { Ing trust } \\
\downarrow \text { SWB }\end{array}$ & $\begin{array}{l}\downarrow \text { Females } \\
\downarrow \text { SHealth } \\
\downarrow \text { Adv edu } \\
\downarrow \text { Higher edu } \\
\downarrow \text { Single } \\
\downarrow \text { Married } \\
\uparrow \text { Language } \\
\downarrow \text { Employed } \\
\downarrow \text { In training } \\
\downarrow \text { sWB }\end{array}$ & $\begin{array}{l}\text { 个 } 2 \text { pers } \mathrm{HH} \\
\uparrow 3+\text { pers } \mathrm{HH} \\
\uparrow \text { Ing trust }\end{array}$ & \\
\hline
\end{tabular}

* The order of classes is based on their decreasing level of social embeddedness.

** Arrows show statistically significant differences comparing a class in the row against a class in the column. $\uparrow$ means 'higher', $\downarrow$ means 'lower'.

$* * *$ Data in bold $=p<0.001$; data without bold $=p<0.05$.

$* * * *$ Abbreviations:

2 pers $\mathrm{HH}=2$-person household

$3+$ pers $\mathrm{HH}=3$ - or more person household

Adv edu = advanced vocational / special secondary / higher (non-university) level of achieved education

Econ strain = economic [financial] difficulties in the household

Higher edu = higher (university) level of educational attainment

In training = currently in education or improving qualifications

Ing trust = in-group trust

Language $=$ knowledge of titular language - native speaker / good knowledge

Outg trust = out-group trust

SHealth = subjective health (very) good

SWB - subjective wellbeing 